\title{
A MONOMANIA INVADE O CAMPO SERENO DA HISTÓRIA.
}

A Emprêsa Calpe Argentina S. A. editou em 1951, na Colec cion Austral, um opúsculo da autoria de Ricardo Levene intitulado: Las Indias no eran colonias.

Como se vê do próprio título dêsse livrinho, o seu autor é daqueles escritores que têm a volúpia de atinar com coisas inéditas em campo já respigado da História, sem perceber que assim procedendo penetra fundo num verdadeiro labirinto.

Infelizmente, aqui entre nós, não faltou quem desse agasalho aos desvaneios dêsse escritor argentino, não só repetindo "ipsis verbis" as suas extravagantes conjecturas, mas acrescentando outras semelhantes que nos transportam ao domínio dos absurdos.

Tendo-se na conta de iluminados, convencidos de que anunciam uma grande novidade histórica, dando-nos a impressão de que realizaram estafantes pesquisas nos vetustos arquivos da Península Ibérica e, em particular, nos de Portugal, dizem à bôca cheia êsses "levenistas" que o Brasil também não foi colônia de Portugal, razão pela qual querem à viva fôrça "rever" as páginas da nossa história e emendá-las no que tange a êsse assunto (1). Vejam bem: "rever", emendar, corrigir as páginas da nossa história, já revistas, já emendadas, já comentadas por historiadores do quilate de Capistrano de Abreu, Rodolfo Garcia, João Ribeiro, Oliveira Lima e Afonso de Taunay!

Não foi colônia de Portugal, gritam de modo a ensurdecer tais "revisores", porque não existe na documentação portuguêsa a partir da data do achamento do Brasil por Álvares Cabral, até aquela da nossa emancipação política, a palavra colônia para designar o nosso país.

Muito bem. Se isso ocorreu só com o Brasil, se o govêrno português daquela época, intencionalmente, evitou chamar o nosso país de colônia por julgar pejorativo tal qualificativo, usando êste

(1). - Queremos nos referir aqui aos organizadores da Jornada Paulista de Revisão da História do Brasil, realizada nos dias 18 a 24 do mês de janeiro do corrente ano na sede do Instituto Histórico e Geográfido de São Paulo, onde a principal tese apresentada a êsse colóquio foi aquela afirmando não ter sido o Brasil uma colônia de Portugal, pelas razões que apontamos e refutamos neste artigo. 
vacábulo tão sòmente para designar as demais possessões ultramarinas, pode-se então tolerar o sofisma dêsses "revisores", admitindose uma amável distinção para com o Brasil e para com os seus fi1hos. Mas a verdade é outra, porque a palavra colônia também não era empregada para designar as demais possessões de Portugal, pelo simples fato de, até o fim do século XVII, não estar em uso tal vocábulo. Quando, porém, no comêço do século XVIII (1712), foi publicado o primeiro dicionário da língua portuguêsa do padre Rafael Bluteau (2), no volume II, página 379 , foi dada a definição de colônia com estas palavras textuais:

"Colônia, gente que se manda para alguma terra novamente descoberta, ou conquistada, para povoar. A mesma terra assim povoada, também se chama colônia".

E, com esta última acepção passou a palavra colônia a ser usada também para designar o Brasil, conforme atestam documentos portuguèses. Exemplos: José Joaquim da Cunha Azeredo Coutinho, da Academia Real das Ciências de Lisboa, na sua conhecida e elogiada obra editada em 1794, ao se referir ao Brasil, inúmeras vêzes usa da palavra colônia:

“...o que certamente seria cortar pela raiz as produções da Colônia, e em conseqüência o comércio da metrópole: logo será necessário navegar para aquela Colônia gêneros que, pouco mais ou menos, se eqüivalam em pêso" (3).

Vejamos agora a palavra oficial. O capitão general Fernando Antônio de Noronha, opinando em 1795 ao Real Erário Português pela extinção da cátedra de latim no Maranhão, assim se expressou com relação aos estudantes brasileiros:

(2) . - Rafacl Bluteau, Vocabulario, portuguez e latino, aulico, anatomico, bellico, botanico, brasilico..., autorizado com exemplos dos melhores escritores portuguezes e latinos... Coimbra, Real collegio das artes da Companhia de Jesus, 17121728 .

E' o dicionário da língua pcrtuguêsa mais antigo e mais importante, tendo aparecido no século XVIII, em 1712. Rafael Bluteau era um estudioso da língua portuguêsa e dedicou grande parte de sua vida na elaboração do dicionário. Lutou com grandes dificuldades, principalmente econômicas. A publicação de sua obra foi patrocinada por $D$. João $V$ a quem eia é dedicada. O dicionário é feito de acôrdo com un plano especial.

Os quatro primeiros volumes foram publicados em Coimbra e, os outros quatro e os dois suplementos, em Lisboa. Verifica-se as dificuldades do autor que levou 26 anos para publicá-los.

Inocêncio Francisco da Silva, na sua obra clássica, Diccionario Bibliographico Portugutues, Lisboa, 1862 volume VII, página 43 , assim se refere a obra de Bluteau: "Os portuguêses lhe devem eterna gratidâo, por lhes dar um dicionário que não tinhım, e de que tanto necessitavam: abalançando-se e conseguinđo êle só com o próprio esfôrço e estudo, o que as academias não puderam vencer antes, nem depois".

(3). - Ensaio econômico sôbre o comércio de Portugal e suas colônias, Lisboa, 1794, Oficinas da Academia Real das Sciencias, página 10. 
“...porque o abuso dos estudantes superiores só serve para nutrir o orgulho próprio dos habitantes do meio dia (sul), e destruir os laços de subordinação politica e civil, que devemos ligar os habitantes das colónias a metrópole" (4).

Mas em realidade, hoje em dia, qual a significação da palavra colônia, que tanta repulsa provoca da parte dos "revisores" da nossa História? Acaso é depreciativa? Em absoluto. A repulsa não obedece a um princípio de bom senso, de lógica, mas tão sòmente a uma desenfreada lusofilia. Ensinam os modernos léxicos de tôdas as línguas, inclusive os da portuguêsa, que colônia é uma certa e determinada porção de terra (firme ou ilha) sujeita às leis e ao govêrno de uma metrópole. Acaso não foi isso o que ocorreu com o Brasil descle o seu achamento por Cabral até a sua independência? Por ventura durante êsse longo período, não foi Portugal a nossa metrópole, não nos impôs as suas leis, não explorou o Brasil a seu bel-prazer, não procurou entravar por todos os meios possíveis o nosso progresso, visando assim retardar a nossa emancipação política? Se isso não é verdade, se Portugal sempre nos tratou com todo o carinho e nos deu ampla liberdade, como então explicar as nossas revoltas contra o jugo português?

Sofismam os "revisores", dizendo que quando o govêrno português se referia ao nosso país, propositalmente dizia: Estado do Brasil. E, exclamam patéticos: eis aqui a prova documental de que o Brasil não foi colônia de Portugal!

Ora, nós sabemos muito bem que a palavra estado, como a empregamos hoje em dia, tem a significação bem nítida de país politicamente organizado, independente, regido por leis elaboradas pelos representantes de seu povo, existindo nele os três poderes que caracterizam perfeitamente a soberania: o legislativo, o judiciário e o executivo. Acaso isso ocorria no Brasil desde o século XVI até o comêço do XIX, tendo o vocábulo estado, naquela época, a mesma significação que tem hoje?

O citado vocabulário do padre Rafael Bluteau, volume II, página 302, assim define estado:

\section{principe". \\ "Estado, as lerras do senhorio ou domínio de algum}

Antônio de Moraes Silva (5), que reformou o dicionário de Bluteau, no volume I da sua obra editada em Lisboa em 1789, diz à página 287 o seguinte, referindo-se ao vocábulo estado:

(4). - Cadido Mendes de Almeida, Direito Ecolesiastico Brasileiro, Rio de Janeiro, 1866, tomo I, parte I, nota no rodapé da página CLI.

(5). - Diccionario da lingua portugueza... Tiraram-se várias edições. A primeira em 1789, a segunda em 1823, a quarta em 1831 e a sétima*em 1877. Em 1922 foi tirada uma ediçáo facsímile da segunda, comemorativa do Centenário da Independência do Brasil. As edições mais importantes são a segunda e a quarta, sendo melhor a segunda, tanto assim que dela fizeram a edição comemorativa diudida. 


\section{"As terras de algum Senhor. Os estados de Braganģi ou da casa de Bragança".}

Agora os leitores vão ver na prática, a confirmação de que as definições de estado por Bluteau e Moraes, estão exatas. No Regimento do Conselho Ultramarino, em 1669, existe uma passagem onde o rei de Portugal declarou:

"Ao dito Conselho hei por bem que pertençam tôdas as matérias que forem tocantes aos ditos estados da fndia, Brasil, Guiné, ilhas de São Tomé e Cabo Verde e de tôdas as partes ultramarinas" (6).

Diante dos dizeres insofismáveis do tópico citado do Regimento aludido, fica provado que a paiavra estado tinha naquela época a significação pura e simples de possessão ou melhor de colônia. E note-se, que o nosso caro Brasil está, no tópico citado, eqüiparado à Guiné, às ilhas de São Tomé, Cabo Verde e a outras possessões portuguêsas ultramarinas de somenos importância.

Se êste nosso raciocínio está errado, se Guiné, ilhas de São Tomé, Cabo Verde, Açores, Madeira, etc., à semelhança do Brasil, não foram colônias de Portugal, mas sim estados na moderna acepção, como desejam os "revisores", então pela fôrça da lógica Portugal não teve colônias e a sua expansão no mundo não passa de uma grande ilusão! Mas... c diabo é que até bem pouco tempo existiu em Portugal o Ministéric das Colônias, ora denominado Ministério do Ultramar.

Na mesma época em que o nosso país era chamado Estado do Brasil, os políticos tanto de Portugal como da Espanha, cautelosamente faziam figurar êstes dois países, não como estados, mas sim como nações, nos famosos tratados de Madrí de 1750 e Santo Ildefonso de 1777 . Por que essa distinção tão acentuada entre eslado e nação, estabelecida pela diplomacia portuguêsa e espanhola? Simplesmente porque tanto Portugal como a Espanha, não eram estados na acepção que então davam a essa palavra, não eram colônias como o.Brasil, mas sim países no gôzo de plena soberania, já naquela época denominadas nações, com a significação que hoje em dia tem êste vocábulo. Mas não é tudo. Nesses mesmos tratados as possessões que Portugal e Espanha possuiam tanto na África como na Ásia e na América, eram chamadas colônias, dominios ou territórios. No entanto não há a menor referência visando distinguir o Brasil das colônias portuguêsas (7). Isto é muito significativo para quem não está obcecado, o que infelizmente não ocorre com os ilustres "revisores":

(6). - Anais da Biblioteca Nacional do Rio de Janeiro, volume XXIX, página 120.

(7) : - José Carlos de Macedo Soares, Fronteiras do Brasit no Regime Colonial, Rio do Janeiro, 1939, páginas 141 a 157 e 171 a 189 . 
Seria enfadonho transcrevermos aqui tôda uma série interminável de cartas régias e alvarás que, não só provam ter sido o Brasil uma colônia de Portugal, mas que mostram a ação governamental de Portugal em tratar o Brasil como uma colônia. Em todo o caso, como "amostra do pano", citaremos algumas dessas cartas régias e alvarás:

Carta Régia de $10^{\circ}$ de março de 1590 , proibindo a plantação e cultura de vinhas.

Intimação de 19 de junho de 1578, feita à Câmara de São Vicente, proibindo que o ferreiro Bartolomeu Fernandes, único no lugar, ensinasse o seu ofício aos da terra.

Alvará de 12 de maio de 1680 , obrigando os sapateiros a só trabalhar em couros que viessem preparados de Portugal.

Alvará de 27 de novembro de 1687, proibindo que os navios saídos do Brasil tocassem em qualquer pôrto estrangeito.

Lei de 20 de fevereiro de 1690, proibindo o uso de outro sal que não fôsse o vindo de Portugal e que aqui chegava por preço exorbitante, possuindo o Brasil, como possuia, excelentes e riquíssimas salinas que já eram conhecidas na época.

Provisão Régia de 3 de setembro de 1695, proibindo o uso de aguardente do país.

Alvará de 26 de junho de 1702, probindo a cultura do arroz.

Carta Régia de 18 de setembro de 1706 , probindo os molinetes de cana.

Carta Régia de 28 de fevereiro de 1707, proibindo a entrada de estrangeiros residentes no Rio de Janerio e expulsando os existentes.

Alvará de 17 de fevereiro de 1711 , proibindo a imigração para o Brasil.

Carta Régia de 18 de novembro de 1715, proibindo o levantamento de engenhos de açúcar em Minas Gerais.

Alvará de 20 de março de 1720 , proibindo letras impressas no Brasil.

Ordem Régia de 19 de fevereiro de 1724, determinando que as promoções de alferes para cima fôssem feitas por el-Rei, mão podendo aproveitar as mesmas aos filhos do Brasil.

Aviso de 14 de setembro de 1725, ordenando não se introduzir na Capitania do Rio de Janeiro o sabão. O povo acabou fabricando. Ver, adiante, a ordem proibindo êsse fabrico.

Aviso Régio de 27 de janeiro de 1726, estabelecendo iníqüas restrições aos mestiços, que não podiam ocupar cargos públicos ou casar com brancas. 
Ordem Régia de 10 de janeiro de 1727 , determinando que a justiça não executasse particulares duranie a cobrança do impôsto dos quintos, feita pelo govêrno.

Carta Régia de 27 de abril de 1727, proibindo a continuação de aberturas de estradas para Minas Gerais e Mato Grosso.'

Carta Régia de 30 de abril de 1727, proibindo estradas novas para São Paulo e Minas Gerais.

Carta Régia de 10 de janeiro de 1730 , proibindo a navegação no rio Tocantins e abertura de estradas no Maranhão.

Carta Régia de 26 de abril de 1730, proibindo correio por terra, no Brasil.

Carta Régia de 18 de agôsto de 1730 , determinando que não se façam descobertas de novas minas, sem licença do rei.

Carta Régia de 15 de setembro de 1730, proibindo estradas novas para São Paulo e Minas Gerais.

Aviso do Conselho Ultramarino de 26 de outubro de 1733, proibindo nova estrada para Goiás.

Ordem Régia de 27 de março de 1734, proibindo os magistrados se casarem no Brasil.

Carta Régia de 3 de janeiro de 1735, ordenando que todo o diamante encontrado com mais de 24 quilates passava a pertencer à Corôa de Portugal.

Carta Régia de 20 de março de 1736, proibindo que viessem, procedentes das ilhas, mais de cinco navios por ano.

Tratado de 13 de janeiro de 1750, mandando fechar a navegação do rio Amazonas.

3ando de 31 de julho de 1751, mandando expulsar os ourives de Minas.

Carta Régia de 18 de junho de 1761, proibindo a entrada $\theta$ saída de mulas $\epsilon$ machos, mandando-os até matar, no caso de infração, atendendo ao prejuízo que tinham os criadores de cavalos, em Portugal.

Carta Régia de 30 de junho de 1766, proibindo em todo o Brasil o ofício de ourives.

Alvará de 5 de fevereiro de 1767 , proibindo a fabricação de sabão no Brasil.

Carta Régia de 19 de junho de 1771, proibindo o fabrico de açúcar no Maranhão. 
Bando do Governador de Minas Gerais de 4 de julho de 1775, mandando acabar com as fábricas de chapéus e tecidos de algodão em Minas Gerais.

Ordem Régia de 5 de julho de 1776, proibindo a entrada, mesmo em arribada, a qualquer navio americano, uma vez que deviam ser-1hes negados todo e qualquer socôrro.

Lei de $10^{\circ}$ de outubro de 1777 , ordenando que todo português que possuisse determinada fortuna fôsse embarcado para Portugal.

Alvará de 3 de janeiro de 1785, proibindo a venda de qualquer espécie de navio para o Brasil.

Alvará de 5 de janeiro de 1785, mandando acabar com tôdas as fábricas do Brasil, uma das maiores injustiças praticadas pelo govêrno português.

Alvará de 16 de dezembro de 1794, proibindo a remessa de livros e papéis para o Brasil, o que importava no desêjo de manter o povo brasileiro na maior ignorância.

Ordem Régia de 5 de junho de 1802, proibindo que os governadores recebessem, no Brasil, em audiência, pessoas que não estivessem vestidas com roupas fabricadas com tecidos importados de Portugal.

Aviso de 18 de junho de 1800 , ao capitão general de Minas Gerais, repreendendo a Câmara Murnicipal de Tamanduás, por ter instituído uma escola primária.

Só o fato do govêrno português ter conservado fechados os portos do Brasil, desde o seu achamento em 1500 por Cabral até 1808 , isolando-o do resto do mundo, é fato que só pode existir nas relações entre metrópole e colônia, visto que desde a mais remota Antigüidade as nações sempre mantiveram entre si relações comerciais, a princípio por meio de trocas de produtos e mais tarde com a circulação de moedas, bem como alianças ofensvias e defensivas no caso de guerras.

À última hora, desesperadamente, os "revisores" recorrem a mais um novo argumento pueril, tentando provar não ter sido o Brasil colônia de Portugal.

Tal aberração consiste em dizer que, durante o longo tempo em que o nosso país esteve sob o domínio de Portugal, os nascidos no Brasil não eram brasileiros mas sim portuguêses, não tendo havido a menor distinção entre "os portuguêses do Brasil e os portuguêses da metrópole".

Para provarmos a fragilidade dêsse argumento, não temos necessidade de dar tratos à imaginação, pois que neste próprio artigo 
estão transcritas algumas ordens régias que evidenciam a manifesta distinção que o govêrno português sempre fêz entre brasileiros e portuguêses. Vamos repeti-las: ordem régia de 19 de fevereiro de 1724, determinando que as promoções de alferes para cima fôssem feitas pelo rei, não podendo ser aproveitados os filhos do Brasil; aviso régio de 27 de janeiro de 1726 , estabelecendo restrições aos mestiços do Brasil que não podiam ocupar cargos públicos nem casar com brancas; ordem régia de 27 de março de 1734, proibindo os magistrados de se casarem no Brasil. 'Inúmeras ordens régias. semelhante a essas, são encontradas nas ordenações do reino.

T. O. MARCONDES DE SOUZA

Da Sociedade de Estudos Históricos de São Paulo e da Société des Américanistes de Paris. 